\title{
Iron supplementation, maternal packed cell volume, and fetal growth
}

\author{
Elina Hemminki, Ulla Rimpelä
}

\begin{abstract}
Previous studies have found that there is a correlation between mothers' haemoglobin concentration or packed cell volume and infants' birth weight, and that iron supplementation increases mothers' haemoglobin concentration. The purpose of this study, using the data of a large randomised trial on iron prophylaxis during pregnancy, was to find out whether iron supplementation causes fetal growth to deteriorate. At their first antenatal visit, 2912 pregnant women were randomised into non-routine iron and routine iron supplementation. The mean length of gestation was shorter in the non-routine group. Birth weight did not differ between the groups, but due to longer gestations boys in the group receiving routine iron were taller than in the nonroutine group. In both groups, whether studied by various values of packed cell volume or correlation coefficients, the lower the packed cell volume, the heavier and taller the infant and heavier the placenta. These negative correlations could be seen even with a packed cell volume measured early in pregnancy. Standardising for blood pressure did not influence the correlation coefficients. The correlation between a high ratio for packed cell volume and poor fetal growth thus may not be caused by iron supplementation, nor mediated by blood pressure, but by some other mechanism.
\end{abstract}

Several surveys in the 1950 s and 1960s found that a mother's anaemia and/or low serum iron was related to the small size and mortality of the infant. ${ }^{1-8}$ These studies, however, did not consider confounding factors such as low social class and the mother's illnesses, and the correlations were usually obtained only with very low haemoglobin values. Recent studies excluding mothers with very low haemoglobin concentrations have found an inverse association between birth weight and haemoglobin concentration in late pregnancy. ${ }^{9-11}$ Other studies have found a $\mathrm{U}$ shaped relation between preterm birth, infant's mortality and weight, and the haemoglobin concentration in early pregnancy 12 or the lowest recorded haemoglobin. ${ }^{12-15}$ Mothers having infants small for their gestational age have higher haemoglobin concentrations in late pregnancy than do other mothers. ${ }^{16-19}$

Supplying iron increases haemoglobin concentrations. Thus an important question is whether iron supplementation contributes to the relation between high haemoglobin concentration and poor outcome, or whether high haemoglobin and poor obstetric outcome are both related to low plasma volume. ${ }^{10} 1220$ Because of selection to iron treatment by haemoglobin concentration, this question can be answered only by studies using experimental designs. Using data of a large randomised trial comparing non-routine and routine iron prophylaxis during pregnancy, we describe the relation of fetal growth to iron supplementation and the mother's packed cell volume and blood pressure.

\section{Subjects and methods}

The study design, methods, and population have been reported in detail previously. ${ }^{21}$ In brief, a multicentre trial comparing two policies of iron prophylaxis in pregnant women was carried out within routine health services. All mothers entering the 27 participating maternity centres were included in the study with the following exceptions: mothers with a serious chronic disease, a packed cell volume $\leqslant 0.32$ or haemoglobin $\leqslant 110 \mathrm{~g} / \mathrm{l}$, the likelihood of moving from the area before the birth of the child, or those who were at more than 16 weeks of gestation. Mothers were randomised into nonroutine iron supplementation and routine iron supplementation. The 218 mothers having a spontaneous abortion were excluded leaving 1358 mothers in the group receiving iron nonroutinely and 1336 mothers in the group receiving it routinely.

Mothers in the group receiving iron routinely were recommended pure iron (that is, not in combination preparations) throughout the pregnancy starting at the latest after the 16th week, with the daily dose $100 \mathrm{mg}$ of elemental iron in one dose. If mothers in the non-routine group had packed cell volume $<0.30$ (that is, haemoglobin $<100 \mathrm{~g} / \mathrm{l}$ ) in two consecutive visits, $50 \mathrm{mg}$ iron twice a day for two months, or until the packed cell volume increased to 0.32 (that is, haemoglobin $110 \mathrm{~g} / \mathrm{l}$ ), was to be recommended. Later during the trial because of midwives' wishes the limit for starting iron was, after 33 weeks' gestation, raised to a packed cell volume $<0.31$ (that is, haemoglobin $<105 \mathrm{~g} / \mathrm{l}$ ). Compliance as reported by the mothers themselves was satisfactory. ${ }^{21}$ The varying intake of iron in the two groups was reflected also in packed cell volume values (see results).

Data were collected on six different forms, one filled out by the midwives in the maternity centres, four filled out by the mothers, and one completed blindly by a research assistant from the infant's hospital record. Midwife forms were obtained for all but 10 mothers. These 
asked for routinely made measurements of packed cell volume or haemoglobin and blood pressure around the 12th, 20th, 28th, and 36th week. Equipment available in the centre determined whether packed cell volume $(91 \%$ of the mothers) or haemoglobin concentration was used. Pack cell volume was measured for capillary blood by the centrifuge method. We changed haemoglobin concentrations into packed cell volume by a formula obtained from the local laboratory: packed cell volume $=$ (haemoglobin $+3 \cdot 171) / 3 \cdot 488$. Placental weight was also obtained from the form filled in by the midwife.

The best estimate of the length of gestation was drawn from the infant's hospital record, completed from the midwife's questionnaire for 15 infants whose records were not found, and rounded off to the nearest week. (Clinicians define gestation length by combining information from various sources, including ultrasound, history of last menstrual period, and clinical signs. The accuracy of measurements may vary from one infant to another, but we assume any inaccuracies to be similarly distributed in the two groups.) In addition, gestation length was calculated in days from the last menstrual period. Unless otherwise specified, the best estimate is used in analyses. Birth weight, birth length, and head circumference were determined from the infant's record. Infants whose weight fell below the 10th centile for that gestational age ${ }^{19}$ were called small for their gestational age. Growth after birth was calculated by subtracting from each infant's weight in the postpartum check up her/his birth weight (g) and dividing by the age (in days).

To learn the prognostic value of the packed cell volume, mothers were classified by the result in the 12 th week $(\leqslant 0.35,0.36-0.38$, $0.39-0.41, \geqslant 42)$, and the 28th week $(\leqslant 0.32$, $0.33-0.35,0.36-0.38, \geqslant 0.39$ ); mothers with unknown values $(n=59$ and 76$)$ were excluded from these analyses.

Pearson's correlation coefficient ( $r$ ) and partial correlation coefficients standardised for other variables were calculated by the BMDP statistical package. Statistical significances were tested by $\chi^{2}$ test (distributions), the test of two proportions (percentages), and $t$ test (means).

\section{Results}

GESTATION LENGTH AND GROWTH BY IRON SUPPLEMENTATION

The mean length of gestation was somewhat shorter in the non-routine group, but was signi- ficant only among boys (table 1). In the nonroutine group somewhat more girls were born in the 39 th week $(21.0 \%$ compared with $16.8 \%)$ and fewer in the 41 st week or later $(33.4 \%$ compared with $38.0 \%$ ) than in the group receiving routine iron. Among boys there were more preterm births ( $<37$ weeks) in the non-routine group $(4 \cdot 8 \%$ compared with $2 \cdot 6 \%)$ and fewer births in the 41 st week or later $(34.9 \%$ compared with $39 \cdot 8 \%$ ). When gestation length was calculated from the last menstrual period, excluding women having gestation $\geqslant 46$ weeks, the mean gestation length was 39.9 weeks in the non-routine group and 40.1 weeks in the group receiving routine iron $(p<0.05)$. These differences were also found when only women with a spontaneous start of labour were studied.

The boys in the group receiving routine iron were, as a mean, $36 \mathrm{~g}$ heavier (not a significant difference) and $0.2 \mathrm{~cm}$ taller (table 1). This was due to longer gestation rather than quicker growth, however, and the mean birth weights in each gestation age were similar. Among girls, all indicators of growth (birth weight, length, head circumference, both means, distributions, and gestation specific values, and proportion of infants small for gestational age) were similar in the non-routine group and group receiving routine iron. Growth from birth to the postpartum examination was similar in the two groups.

In both groups boys were taller and heavier than girls, but that difference emerged only in the 38th week for height and in the 40th week for weight.

\section{GESTATION LENGTH AND GROWTH BY PACKED} CELL VOLUME

With gestation, the mothers' packed cell volume became lower in the non-routine group than in the group receiving routine iron (figure). In the non-routine group, the packed cell volume decreased until the 28th week. In the group receiving routine iron the decrease stopped by the 20th week. The higher the initial packed cell volume ratio, the greater the decrease in both groups.

We investigated the means and distributions of birth weight, birth length, and gestation length in the different groups of packed cell volume measurements in the 12th and 28th week. In the groups of high packed cell volume, mean birth weight and birth length were lower, and the proportion of infants weighing less than $2500 \mathrm{~g}$ was higher. Table 2 gives the results by the packed cell volume result in the 28 th week. Similar results were obtained in the 12 th week,

Table 1 Comparison between 1355 infants whose mothers received iron non-routinely and 1335 whose mothers received iron routinely. Values are expressed as mean (SD) except where otherwise stated

\begin{tabular}{|c|c|c|c|c|}
\hline & \multicolumn{2}{|l|}{ Girls } & \multicolumn{2}{|l|}{ Boys } \\
\hline & $\begin{array}{l}\text { Non-routine } \\
\text { iron } \\
(n=670)\end{array}$ & $\begin{array}{l}\text { Routine } \\
\text { iron } \\
(n=689)\end{array}$ & $\begin{array}{l}\text { Non-routine } \\
\text { iron } \\
(n=685)\end{array}$ & $\begin{array}{l}\text { Routine } \\
\text { iron } \\
(n=646)\end{array}$ \\
\hline $\begin{array}{l}\text { Gestation (weeks) } \\
\text { Birth weight (g) } \\
\text { Length at birth (cm) } \\
\text { Infants small for gestational age (\%) } \\
\text { Growth after birth ( } g / \text { day) }\end{array}$ & $\begin{array}{l}39 \cdot 7(1 \cdot 9) \\
3511(542) \\
49 \cdot 7(2 \cdot 5) \\
6 \cdot 3(10 \cdot 4) \\
27 \cdot 9(10 \cdot 9)\end{array}$ & $\begin{array}{l}39 \cdot 8(1 \cdot 9) \\
3515(544) \\
49 \cdot 7(2 \cdot 4) \\
6 \cdot 7(10 \cdot 1) \\
27 \cdot 3(10 \cdot 1)\end{array}$ & $\begin{array}{l}39 \cdot 7(2 \cdot 0)^{*} \\
3622(576) \\
50 \cdot 5(2 \cdot 5)^{*} \\
5 \cdot 7( \\
31 \cdot 4(11 \cdot 7)\end{array}$ & $\begin{aligned} 39 \cdot 9 & (1 \cdot 8)^{*} \\
3658 & (568) \\
50 \cdot 7 & (2 \cdot 4)^{*} \\
4 \cdot 2 & \\
32 \cdot 2 & (13 \cdot 0)\end{aligned}$ \\
\hline
\end{tabular}

*Boys whose mothers received iron non-routinely compared with boys whose mothers received iron routinely: $p<0 \cdot 05$. 
Table 2 Birth weight and gestational age by packed cell volume in mothers during 28 th week

\begin{tabular}{|c|c|c|c|c|c|c|c|c|}
\hline & \multicolumn{4}{|c|}{ Packed cell volume:non-routine iron $(n=1319)$} & \multicolumn{4}{|c|}{ Packed cell volume:routine iron $(n=1299)$} \\
\hline & $\leqslant 0 \cdot 32$ & $0 \cdot 33-0.35$ & $0.36-0.38$ & $\geqslant 0.39$ & $\leqslant 0 \cdot 32$ & $0.33-0.35$ & $0.36-0.38$ & $\geqslant 0.39$ \\
\hline \multirow{4}{*}{$\begin{array}{l}\text { No of mothers } \\
\text { Mean (SD) birth } \\
\text { weight (g) } \\
\text { Birth weights } \\
<2500 \mathrm{~g}(\%) \\
\text { Infants whowere small } \\
\text { for gestational age (\%) }\end{array}$} & 162 & 462 & 513 & 182 & (58) & 395 & 586 & 260 \\
\hline & $3690(531)$ & $3581(532)^{*}$ & $3574(538)^{*}$ & $3421(643)^{* *}$ & $3556(536)$ & $3618(520)$ & $3601(552)$ & $3522(579)^{*}$ \\
\hline & 1.9 & $2 \cdot 6$ & $2 \cdot 1$ & $7 \cdot 7^{*}$ & $(5 \cdot 2)$ & $1 \cdot 3$ & $2 \cdot 4$ & $5 \cdot 0^{* *}$ \\
\hline & $5 \cdot 6$ & $5 \cdot 0$ & $5 \cdot 8$ & $9 \cdot 3$ & $(8 \cdot 6)$ & $4 \cdot 3$ & 4.9 & 6.9 \\
\hline
\end{tabular}

${ }^{*}=\mathrm{p}<0.05$, and ${ }^{* *}=\mathrm{p}<0.01$ when compared with those with packed cell volume $\leqslant 0.32$ in the group who received iron non-routinely, and when compared with those with packed cell volume $0.33-0.35$ in the group who received iron routinely (because of the small and when compared with those with packed cell volume $0 \cdot 33$

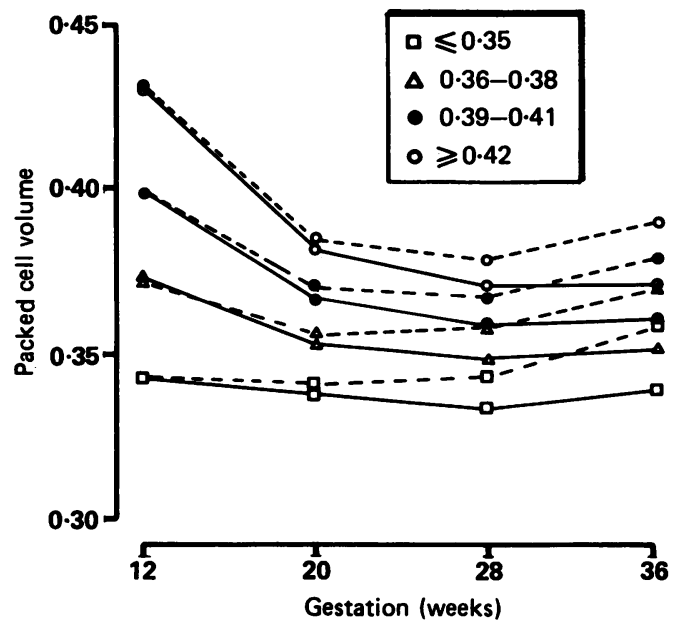

Changes in mean packed cell volume measured in the 12th week of gestation in mothers receiving iron non-routinely (solid line) and those receiving it routinely (broken line).

but the differences were not larger in the nonroutine than in the group receiving routine iron as in the 28th week. The relation between packed cell volume in the 12 th and 28 th weeks and gestation length was weaker and not significant.

We also studied the relation between packed cell volume in the $12 \mathrm{th}, 20 \mathrm{th}, 28 \mathrm{th}$, and 36 th weeks and birth weight, birth length, head circumference, and gestation length by counting correlation coefficients. Weak negative correlations to weight and length could be seen in all packed cell volume measurements, but were usually strongest in the 36th week: the lower the packed cell volume the heavier and taller the infant. Correlations with head circumference were also negative, but weaker than those of weight or length. The negative correlation of the packed cell volume with gestation length was weaker than that with weight, and significant only in the iron group in the 36th week.

INTERVENING VARIABLES

To examine the relation between high packed cell volume and low birth weight we studied blood pressure and placental weight as possible intervening variables. Both groups were fairly similar to each other in blood pressure, proteinuria, and mothers' weight gain during pregnancy, and in placental weight. In both groups, high blood pressure, especially diastolic, correlated positively with the packed cell volume in the 36th week, negatively with gestation length, and weakly with birth weight (table
Table 3 Correlations between mothers' diastolic blood pressure in the 36 th week and placental weight with packed cell volume, length of gestation, and birth weight

\begin{tabular}{|c|c|c|}
\hline & $\begin{array}{l}\text { Non-routineiron } \\
(n=1120-1206)\end{array}$ & $\begin{array}{l}\text { Routine iron } \\
(n=1127-1181)\end{array}$ \\
\hline $\begin{array}{l}\text { Diastolic blood pressur } \\
\text { Packed cell volume, } \\
\text { 36th week } \\
\text { Length of gestation } \\
\text { Birth weight }\end{array}$ & $\begin{array}{r}0 \cdot 20^{* * *} \\
-0 \cdot 17^{* * *} \\
-0 \cdot 11^{* * *}\end{array}$ & $\begin{array}{c}0 \cdot 20^{* * *} \\
-0 \cdot 16^{* * *} \\
-0 \cdot 09^{* *}\end{array}$ \\
\hline $\begin{array}{l}\text { Placental weight: } \\
\text { Packed cell volume, } \\
\text { 36th week } \\
\text { Length of gestation } \\
\text { Birth weight }\end{array}$ & $\begin{array}{r}-0.13^{* * *} \\
0 \cdot 26^{* * *} \\
0.68^{* * *}\end{array}$ & $\begin{array}{c}-0.07^{*} \\
0.28^{* * *} \\
0.68^{* * *}\end{array}$ \\
\hline
\end{tabular}

Table 4 Raw and partial correlation coefficients (standardised for systolic and diastolic blood pressure) of the packed cell volume in the 36th week with gestation length, birth weight, and placental weight

\begin{tabular}{|c|c|c|c|c|}
\hline & \multicolumn{2}{|c|}{$\begin{array}{l}\text { Non-routine iron } \\
(n=1153-1177)\end{array}$} & \multicolumn{2}{|c|}{$\begin{array}{l}\text { Routine iron } \\
(n=1154-1168)\end{array}$} \\
\hline & Raw & Partial & Raw & Partial \\
\hline $\begin{array}{l}\text { Gestation length } \\
\text { Birth weight } \\
\text { Placental weight }\end{array}$ & $\begin{array}{l}-0.04 \\
-0.13^{* * *} \\
-0 \cdot 13^{* * *}\end{array}$ & $\begin{array}{l}-0.01 \\
-0 \cdot 11^{* * *} \\
-0 \cdot 13^{* * * *}\end{array}$ & $\begin{array}{l}-0 \cdot 09^{* *} \\
-0 \cdot 12^{* * *} \\
-0 \cdot 07^{*}\end{array}$ & $\begin{array}{l}-0 \cdot 07^{*} \\
-0.10^{* * *} \\
-0.07^{*}\end{array}$ \\
\hline
\end{tabular}

3) and birth length. Correlation coefficients with blood pressure in the 12th and 28th week tended in the same direction as those in the 36th week, but were usually smaller, with the exception of packed cell volume, with which the correlations were equally strong.

Weight of placenta correlated positively with birth weight, birth length, and gestation length, and, especially in the non-routine group, negatively with the packed cell volume (table 3 ). On the other hand, there was no correlation between placental weight and systolic blood pressure $(-0.01$ in the 36 th week, both groups combined) and only a weak correlation with diastolic blood pressure $(-0.05$ in the 36th week).

To abolish the association caused by joint correlations with blood pressure, partial correlation coefficients were calculated standardising for blood pressure. Standardisation only marginally changed correlation between packed cell volume and birth weight and placental weight (table 4). Similar changes after standardisation were observed for the measurements of packed cell volume in the 12 th and 28 th weeks.

\section{Discussion}

Mothers having a high packed cell volume had 
lighter infants and smaller placentas, and the negative correlation could be seen both with the packed cell volume in early and late gestation. Correlations with birth length, head circumference, and gestation length were weaker. The inverse association between a high packed cell volume in late pregnancy and poor infant growth has been documented previously, , $^{9-11}$ but in this study it was found also for the packed cell volume measured in early pregnancy. In the study of Murphy et al the association was $U$ shaped. ${ }^{12}$

Iron supplementation increased packed cell volume ratios, but it did not influence birth weight. High packed cell volume ratios relating to poor growth are thus probably caused by factors other than iron. Contrary to our hypotheses no clear sex specific differences in growth by iron supplementation emerged. Our results are contrary to previous controlled trials among pregnant women ${ }^{22-25}$ and among rats, ${ }^{26}$ which have consistently reported lower birth weight in the group receiving iron. However, all studies involved a small number of subjects, and among human beings these differences have not been significant.

As in the study of Murphy et al there was a positive correlation between a high packed cell volume and high blood pressure. ${ }^{12}$ Standardising for blood pressure did not influence the correlations between packed cell volume and birth weight and packed cell volume and placental weight. Thus it seems that packed cell volume does not influence birth weight by blood pressure, but by some other mechanism such as small plasma volume and increased blood viscosity with impaired placental circulation. ${ }^{12} 27-29$ Noteworthy is the fact that the negative correlation with birth weight could be seen even with packed cell volume measured early in pregnancy.

The prediction of poor growth by a high packed cell volume was clearer in the nonroutine group. Apparently iron supplementation transferred several 'healthy women' to the group with a high value, and this diluted the association between the high value for packed cell volume and poor growth of the fetus. Even though routine iron supplementation does not seem to diminish growth, it may impede diagnosis of poor growth.

Gestation length was somewhat shorter in the non-routine group, especially among mothers with boys. The difference was mainly due to different distribution within 39-42 weeks; thus it is possible that iron postpones that start of labour at term. The mechanism remained unclear. It was not through packed cell volume, high blood pressure, or inductions. Nor is it likely to be due to varying calculations of gestation length, because it could be seen also with gestation length calculated from the last menstrual period.

The study was supported by grants from the National Board of Health, the Academy of Finland, the Finnish-Norwegian Medical Foundation, and the Paulo Foundation.

1 Butler NR, Bonham DG. Perinatal mortality. The first report of the 1958 British Perinatal Mortality Survey. Edinburgh: $\mathrm{E}$ and S Livingstone, 1963:71.

2 Kaltreider DF, Johnson JWC. Patients at high risk for low-birthweight delivery. Am $\mathcal{f}$ Obstet Gynecol 1976;124: 251-6.

3 Klein L. Premature birth and maternal prenatal anemia. Am f Obstet Gynecol 1962;83:588-90.

4 Lamberti G. Zur generellen Eisenprophylaxe in der Schwangerschaft. Z Geburtshilfe Perinatol 1973;177:381-6.

5 McFee JG. Anemia: a high-risk complication of pregnancy. Clin Obstet Gynecol 1973;16:153-71.

6 Ontario Perinatal Mortality Study Committee. Report of the perinatal study 1959 in ten university teaching hospitals. Toronto: Department of Health, 1961: table 24 and suppl.

Roszkowski I, Wojcicka J, Zalenska K. Serum iron deficiency during the third trimester of pregnancy: maternal complications and fate of the neonate. Obstet Gymecol 1966; 28:820-5.

8 Van Nagell J, Koepke J, Dilts PV. Preventable anemia and pregnancy. Obstet Gynecol Surv 1971;26:551-63.

9 Higgins AC. Nutritional status and the outcome of pregnancy. Fournal of the Canadian Dietetic Association 1976;37: 17-35.

10 Mau G. Hemoglobin changes during pregnancy and growth disturbances in the neonate. $\mathcal{F}$ Perinat Med 1977;5:172-7.

11 Sagen N, Nilsen ST, Kim HC, et al. Maternal hemoglobin concentration is closely related to birth weight in normal

pregnancies. Acta Obstet Gynecol Scand 1984;63:245-8. Murphy JF, O'Riordan J, Newcombe RG, et al. Relation of
haemoglobin levels in first and second trimesters to outhaemoglobin levels in first and second trimes
come of pregnancy. Lancet 1986;i:992-5.

13 Fedrick J, Anderson ABM. Factors associated with spontaneous preterm birth. Br $\mathcal{f}$ Obstet Gynaecol 1976;83: 342-50.

14 Garn SM, Ridella SA, Petzold AS, et al. Maternal hematologic levels and pregnancy outcomes. Semin Perinatol 1981; 5:155-62.

15 Ratten GJ, Beischer NA. The significance of anaemia in an obstetric population in Australia. Fournal of Obstetrics and Gynaecology of the British Commonwealth 1972;79:228-37.

16 Dunlop $\mathbb{W}$, Furness C, Hill LM. Maternal haemoglobin concentration, haematocrit and renal handling of urate in pregnancies ending in the births of small-for-dates infants. Br $₹$ Obstet Gynaecol 1978;5:938-40.

17 Koller O, Sagen N, Ulstein M, et al. Fetal growth retardation associated with inadequate haemodilution in otherwise uncomplicated pregnancy. Acta Obstet Gynecol Scand 1979; 58:9-13.

18 Koller O, Sandvei R, Sagen N. High hemoglobin levels during pregnancy and fetal risk. Int $\mathcal{f}$ Gynaecol Obstet 1980; 18:53-6.

19 Ylä-Outinen A. Intra-uterine growth retardation. Acta

Universitatis Tamperensis Series $A$ 1984:179.
20 Redman CWG. Maternal plasma volume and disorders of pregnancy. $B M \mathcal{F}$ 1984;288:955-6.

21 Hemminki E, Uski A, Koponen P, Rimpelä U. Iron supplementation during pregnancy-experiences of a randomized trial relying on health service personnels. Controlled Clin Trials 1989;10:290-8.

22 Fleming AF, Martin JD, Hahne R, et al. Effects of iron and folic acid antenatal supplements on maternatal haematology and fetal well-being. Med $\mathcal{f}$ Aust 1974;2:429-36.

23 Paintin DB, Thomson AM, Hytten FE. Iron and the haemoglobin level in pregnancy. Foumal of Obstetrics and Gynaecogloby of the British Commonwealth 1966;73:181-90.

24 Puolakka J. Serum ferritin as a measure of iron stores during pregnancy. Acta Obstet Gynecol Scand 1980;suppl 95.

25 Taylor DJ, Mallen C, McDougall N, et al. Effect of iron supplementation on serum ferritin levels during and after
pregnancy. Br $\mathcal{F}$ Obstet Gynaecol 1982;89:1011-7.

26 Fairweather-Tait SJ, Payne V, Williams CM. The effect of iron supplements on pregnancy in rats given a low-zinc iron supplements on pregnancy
diet. $\mathrm{Br} \mathcal{F}$ Nutr 1984;52:79-86.

27 Hytten FE, Leitch I. The volume and composition of the blood. The physiology of human pregnancy. 2nd Ed. Oxford: Blackwell, 1971:1-43.

28 Koller $O$. The clinical significance of hemodilution during pregnancy. Obstet Gynecol Surv 1982;37:649-52.

29 Taylor DJ, Lind T. Red cell mass during and after normal pregnancy. Br $\mathcal{F}$ Obstet Gynaecol 1979;86:364-70. 